\title{
Electric utilities, fuel use, and responsiveness to fuel prices
}

2014

Energy Economics

DOI: 10.1016/j.eneco.2014.05.009

Daniel Matisoff ${ }^{1}$

Assistant Professor

Georgia Institute of Technology

Douglas Noonan

Associate Professor

Indiana University - Purdue University - Indianapolis

Director of Research, IU Public Policy Institute

Jinshu Cui

Ph.D. Student

University of Southern California

${ }^{1}$ Corresponding Author

Daniel Matisoff

School of Public Policy

Georgia Institute of Technology

685 Cherry St

Atlanta, Georgia 30332-0345

USA

matisoff@gatech.edu 


\section{Abstract}

This research tests the impact of changes in fuel price to explain fuel use by electric utilities. We employ a three-stage least squares model that explains changes in fuel use as a function of changes in three fuel prices. This model is repeated across sub-samples of data aggregated at the plant level and operating holding company level. We expect that plants and holding companies reduce fuel use when fuel prices rise. Several fuel substitution effects within and across plants and holding companies are demonstrated, as well as several frictions. At the plant level, higher prices of natural gas lead to less natural gas consumption, less coal consumption, and more fuel oil consumption. At the operating holding company level, results demonstrate the inelasticity of coal use and the increases of natural gas in response to higher coal prices. Subsamples demonstrate heterogeneity of results across different plants. Results emphasize that technological, market, and regulatory frictions may hinder the performance of energy policies.

\section{Keywords:}

Fuel switching; electric utilities; utility regulation; fuel use; three-stage-least-squares JEL codes: Q40; Q41; Q48; D22; L94 


\section{Introduction}

While new natural gas capacity is approximately 30 percent cheaper than new coal capacity (Energy Information Administration, 2011a) and natural gas is currently less expensive than coal, the carbon intensity of electricity production has increased in recent years due to increased use of coal (Energy Information Administration, 2011d). The factors that drive fuel use and capital investment decisions in electric utilities are the result of interactions in electricity and fuel markets, the regulatory environment, and decision-making by electric utilities. An improved understanding of the responsiveness of power plants and companies to price trends can highlight the important drivers of fuel mix in electricity markets.

Electricity and fuel markets send signals to firm managers, leading them to invest in power plant technologies, utilize fuels to generate electricity, and enter into contracts to procure fuel supplies. An efficient market provides connectivity between firm managers, consumers, and inputs to electricity production and allows firm managers to generate electricity cheaply and provide that electricity at low cost to consumers. However, a variety of market characteristics may lead to inefficient outcomes. Most electricity markets are not competitive - they are characterized by monopolies and frictions, and they are regulated by public service commissions (PSCs). Electricity markets have by high costs of entry and exit and barriers to entry to the grid, all of which make the electricity market susceptible to market distortions. How electricity utilities respond to (noncompetitive) energy markets’ price signals remains a critical empirical question for at least the short- and intermediate-future.

Previous research examining utility responses to fuel prices began in the 1970s. Models allow for cross-price elasticities of fuel demand and fuel substitution over the short run, via fuel switching (Atkinson and Halvorsen, 1976) or the long run, through investment in new boiler 
technology (Joskow and Mishkin, 1977; Seifi and McDonald, 1986). Following Atkinson and Halvorsen (1976), we measure three separate inputs to electricity production (coal, oil, and natural gas) and consider fuel switching to be synonymous with fuel substitution - or a shift in the generation of electricity attributable to a particular factor input. We seek to build on this early research with more recent data and methodologies. In particular, we employ panel data and take advantage of within-plant variation, in contrast to Atkinson and Halvorsen who measured fuel substitution through cross-sectional data and sub-samples of power plants. We also examine differences in plant-level behavior and operating holding company-level behavior (hereafter referred to as holding company level), which allows our estimation to capture differences in within-plant behavior versus differences in within-firm behavior.

Recent literature, employing firm-level data in Germany from 1968 to 1998 suggests that fuel substitution in Germany is inelastic, arguing that either various regulatory interventions or technological reasons prevent fuel substitution in the short term and that older models and methods were mis-specified (Tauchmann, 2006). Despite early research that suggested that fuel use by electric utilities in the U.S. is elastic, a variety of research suggests that there are political, regulatory, market, and technological frictions to fuel substitution in the U.S. It remains unclear whether frictions in U.S. electricity markets make fuel use inelastic to fuel prices, and the extent to which electric utilities are able to engage in input substitution across different fuel sources.

We present a simultaneous equations model that examines the impact of changes in fuel prices on fuel use in the United States. We aggregate data to the power plant level and operating holding company level while utilizing a dataset with fuel use data from 1994 - 2007. We also test the model with a subsample of plants that demonstrate only marginal fuel use adjustments.

\section{Literature Review}

Author's accepted manuscript. Final version published as: Matisoff, D., Noonan, D., \& Cui, J. (2014). Electric utilities, fuel use, and responsiveness to fuel prices. Energy Economics. http://dx.doi.org/10.1016/j.eneco.2014.05.009 
A detailed (although dated) literature has addressed the use of fossil fuel in electric utilities. We acknowledge that additional literature exists that addresses fuel switching by households, firms, and other end users (e.g. Mansur et al. (2008)) that we do not address in this review as we limit our study to electric utilities. Early work in this area aggregated fuels as a single input (see Galatin (1968) for a summary of the development of the early literature in fuel switching and Atkinson et al. (1976) for a discussion of the limitations of models that aggregate fuels as a single input). In the 1970s, researchers built in assumptions to allow cross-price elasticities of fuel demand and fuel substitution over the short run, via fuel switching (Atkinson and Halvorsen, 1976) or the long run, through investment in new boiler technology (Joskow and Mishkin, 1977; Seifi and McDonald, 1986). Aggregating to the regional level, Mountain (1982) and Uri (1977) combine short-run and long-run mechanisms showing substantial fuel substitution in the regional electricity supply.

Research has produced mixed results. Research from the U.S. suggests that utilities will substitute fuel over the short run - via fuel switching (Atkinson and Halvorsen, 1976) - and this effect translates to national and regional fuel use and substitution (Bopp and Costello, 1990; Mountain, 1982; Uri, 1977). However, more recent evidence from Europe that incorporates panel data techniques suggests that fuel use and fuel switching are inelastic in the short run and long run (Tauchmann, 2006). Tauchmann (2006) argues that previous models may be mis-specified, due to cost-minimization or profit-maximization assumptions and that regulated utilities may not be subject to these market pressures. Further, modeling that relies on static models of electricity production does not appropriately characterize specific features of the electricity sector. Electricity cannot be stored, is subject to long-term planning and contracts, and is subject to regulatory pressure.

Author's accepted manuscript. Final version published as: Matisoff, D., Noonan, D., \& Cui, J. (2014). Electric utilities, fuel use, and responsiveness to fuel prices. Energy Economics. http://dx.doi.org/10.1016/j.eneco.2014.05.009 
The contrast in results across the literature may also be explained by data preprocessing and modeling choices. Atkinson and Halvorsen limit observations to those power plants that utilize multiple types of fuel in power plants; Tauchmann includes all fossil fuel power plants by all utilities in Germany. Atkinson and Halvorsen examine behavior over a larger sample of utilities in the U.S., while Tauchmann’s sample is much more limited (9 firms over 30 years). Atkinson and Halvorsen measure the elasticity of substitution across plants, measuring the average elasticity across subsamples of power plants that switch fuels, while Tauchmann measures within-plant differences over time. Further, there may be differences over time and across country, due to differences in the regulatory environments.

Despite difficulties in appropriately identifying the data generating process, fuel use and fuel switching remain incredibly important in electricity production and the environmental impacts of electricity production. Much of the existing research focuses on national-level trends (e.g., Griffin, 1977; Jones, 1996; Pindyck, 1979; Söderholm, 2000) rather than micro-level behavior that more accurately represents the role of the decision-making unit. Since the 1970s, numerous characteristics of electricity production have shifted. Fuel trading and futures markets play a much greater role in electricity production. Technological options have shifted, with an increased role for multi-fuel boilers and increased efficiency, and state-level regulations have favored efficiency gains and production from renewables.

\section{Theory and Hypotheses}

The electricity generation market is subject to a variety of market, technological, and regulatory frictions. The coal market is characterized by high costs of entry and exit and long contract periods for coal purchases. While figures vary over time and across regions, only a small fraction of coal fuel purchases (3-7\%) are purchased on the spot market, with the median 
contract averaging around 2 years (SNL Energy, 2014). Natural gas, in contrast, has shorter purchase contracts and has about 50 - 60\% of the supply purchased on the spot market, making short-term prices more relevant to decision-makers (SNL Energy, 2014). Oil has typically been used for peak or specialized purposes, also making spot prices more relevant.

Power plants sell electricity under a variety of contract arrangements that are likely to provide short-run operating constraints. Electricity supply contracts, also known as “tolling contracts,” set electricity prices and quantities into the future (Deng and Oren, 2006; Joskow, 2001). Power purchase agreements, which are often part of a project financing package for new generation, can induce increased stability in the electricity supply and set a fixed (or variant) price for electricity, despite changes in the fuel input costs and changes in the spot market price (Joskow, 2001).

Utility decisions are subject to a broad array of regulatory pressures from the state and federal levels that impact the types of investments and costs that a utility is allowed to pass along to consumers and what types of expenses a utility is able to generate profit from. ${ }^{1}$ While the Federal Electricity Regulatory Commission rules are the same across states, state utility commissions are largely responsible for determining rules related to capital (fixed) cost recovery and variable (fuel and maintenance cost) recovery. Coal plants, with high capital costs and lower fuel costs, represent a different sort of investment than natural gas plants. Because utilities in

\footnotetext{
${ }^{1}$ If electricity prices were fixed even when a fuel's price rose, we expect a cost-minimizing utility to substitute away from the costlier input. If utilities could "pass through” those higher expenses to ratepayers in the form of higher electricity prices, we would still expect a reduced input demand as the quantity of electricity demanded fell. The magnitudes of the own- and cross-price elasticities would differ between those two cases.
}

Author's accepted manuscript. Final version published as: Matisoff, D., Noonan, D., \& Cui, J. (2014). Electric utilities, fuel use, and responsiveness to fuel prices. Energy Economics. http://dx.doi.org/10.1016/j.eneco.2014.05.009 
most states generate profit based on capital costs, and pass fuel costs along to consumers, utilities are thought to favor high capital-cost investments in coal, over lower capital-cost investments in natural gas (Courville, 1974).

Recent research suggests that state regulatory characteristics may be responsible for distortionary impacts on fuel use decisions. Policies such as Fuel Adjustment Clauses (FACs) hedge utilities from price uncertainty (Graves et al., 2006) and can have distortionary impacts on fuel and investment decisions of utilities (Baron and De Bondt, 1979; Isaac, 1982; Kaserman and Tepel, 1982; Michaels, 1994; Morgan, 1993). Because investment and rate decisions are often passed through a PSC, regulators and regulatory decision-making may distort the investment decisions by regulated utilities (Fremeth and Holburn, 2012). And state regulatory systems, where a wide variety of energy policies have been adopted (Matisoff, 2008) and some repealed, have created an uncertain regulatory climate that has dissuaded investment in new generation (Fabrizio, 2013).

Technological frictions also introduce discontinuities, inflexibilities, and slow pace in responding to market shocks. It is difficult and costly for coal-burning power plants to switch from coal to other fuels. Switching fuels, varying load, or other changes in electricity supply can drive up maintenance costs for plant operators. Coal plants function best when operated continuously and at full capacity, while natural gas plants can be more easily operated at varying capacity. Reducing capacity or shutting down coal boilers also drives up maintenance costs and reduces the life of the plant (Deng and Oren, 2006). Electricity supply contracts, for example, limit the number of times a power plant can be turned on or off, despite the potential for the spark spread (the difference between the price of electricity and the fuel cost to produce 
electricity) to turn negative (Deng and Oren, 2006), suggesting that firms may operate plants at a loss due to technological frictions.

One type of fossil fuel power plant that has grown popular uses a multi-fuel boiler in conjunction with a heat recovery steam generator (HRSG). The boiler can be fueled with natural gas, syngas, or fuel oil. These plants are highly efficient and can be constructed quickly (a 1,000 MW plant may be completed in as little as 18 months from start of construction); however, the economics of such plants are heavily influenced by the volatile price of natural gas. Other multifuel plants can use a combination of coal, natural gas, biomass, and other types of fuel; however, there are additional maintenance costs associated with co-firing or fuel switching. In the longer term, firms can invest in new boilers or convert coal plants to natural gas plants, but these investment decisions may need to pass through the PSCs and are subject to regulatory uncertainty. Difficulty in storage of excess fuel supply and pipeline capacity constraints (which can cause price increases during periods of high demand) also pose frictions in efficient operation of plants.

Despite market and regulatory frictions, traditional economic theory suggests that utilities should adjust coal, natural gas, and oil use in response to prices, and substitute in response to the prices of the other two fuels. However, due to the various frictions that might temper expectations of elastic fuel consumption, the observed elasticity of fuel consumption by utilities remains of interest and can help develop a better understanding of the observed elasticity of consumption decisions by U.S. electric utilities. Current estimates of price elasticities are vital to informing models of evolving fuel mix in the energy sector as various fuels experience different price pressures due to regulatory, supply, or demand shocks.

Author's accepted manuscript. Final version published as: Matisoff, D., Noonan, D., \& Cui, J. (2014). Electric utilities, fuel use, and responsiveness to fuel prices. Energy Economics. http://dx.doi.org/10.1016/j.eneco.2014.05.009 
Extant literature has demonstrated different evidence of this relationship. As discussed above, research from the U.S. indicates substitution among different types of fuel (Atkinson and Halvorsen, 1976) while research based on the European experience suggests fuel use and fuel switching are inelastic (Tauchmann, 2006). Individual plants can shift fuel mix in the short run, by altering the fuel mix in multi-fuel boilers, and by shifting load in a multi-boiler plant. In a longer time horizon, firms can replace boilers to switch fuels.

$H_{1}$ : Power plants respond to changes in fuel prices by shifting their fuel mix.

Holding companies have more opportunities switch fuel than individual power plants. While individual plants can shift fuel between boilers or shift the type of fuel used in a boiler, electric utility holding companies, which generally own multiple power plants, have more flexibility in responding to fuel price changes. Electric utilities can shift their fuel portfolios both within and across plants, shift load across plants, and build or acquire new capacity. We hypothesize that examining behavior at the holding company level will demonstrate greater elasticities than behavior at plant level. It is possible, however, that because fuel choices at the holding company level average responses across an array of power plants, their elasticities may be smaller than at the individual plant level. Technological frictions might lead to discontinuous responses to fuel price shocks at the individual plant level, whereas holding companies’ responses can smooth over multiple "lumpy” plants and exhibit a moderated elasticity. Fuel choices at the holding-company level reflect an average response across their subsidiary plants, thus muting the facility-level responses observed but allowing for shifts across plants to appear in the results. ${ }^{2}$

\footnotetext{
${ }^{2}$ A coal price hike might not be enough to get any of nine plants to alter use but a tenth plant is shutdown entirely, implying a $-10 \%$ reduction in coal use when averaged across the ten units. When those ten
} 
$\mathrm{H}_{2}$ : Electric utilities (holding companies) have greater fuel elasticity than plant-level elasticities.

Natural gas has trended towards relatively shorter contracts from long-term contracts in the past two decades (Petrash, 2006). Short-term contracts make the fuel switching process easier for power plants, allowing for greater elasticity. Additionally, high market volatility has made the natural gas market susceptible to extreme price swings when unexpected changes occur in the market, such as weather-related spikes in demand or supply constraints caused by hurricane damage (Petrash, 2006). Combined with FACs and other regulatory pressures that shelter firms from fuel price risks and favor coal capacity investment, the relative responsiveness of utilities to natural gas and coal prices remains an empirical question. Taken together, tests of these hypotheses across fuel use cast new light on the fuel price elasticities at U.S. power plants. The results also offer some indication about the market and technological frictions present.

\section{Data}

Plant-level data were compiled with the assistance of Indianapolis Power and Light from the Velocity data suite, which relies primarily on data collected from EIA forms 861, 412, 906, 920, 923, and FERC form $1 .{ }^{3}$ In addition, variables are collected to control for plant characteristics. These variables include plant capacity, electricity generation, year of construction,

plants are aggregated to the holding company level, whether the company's response to the price shock is also a $10 \%$ reduction depends on the relative size of that tenth plant.

${ }^{3}$ Because fuel use data, data containing plant characteristics, and firm-level and state-level data were contained in separate datasets, data are merged into one large dataset using plant ID numbers, operator ID numbers, and operator holding company ID numbers. FERC and EIA data were compiled using Ventyx’s Velocity Suite.

Author's accepted manuscript. Final version published as: Matisoff, D., Noonan, D., \& Cui, J. (2014). Electric utilities, fuel use, and responsiveness to fuel prices. Energy Economics. http://dx.doi.org/10.1016/j.eneco.2014.05.009 
and the percentage of electricity generated from coal. ${ }^{4}$ Form EIA-923 collects information from electric power plants in the United States. Data collected on this form include electric power generation, fuel consumption, fossil fuel stocks, delivered fossil fuel cost, combustion by products, operational cooling water data, and operational data for $\mathrm{NO}_{\mathrm{x}}, \mathrm{SO}_{2}$, and particulate matter control equipment. The dataset we use contains the fuel consumption - coal, natural gas, and oil each plant-year, converted to Million Metric British Thermal Units (mmBTU) of 965 power plants from the 50 states of the US during 1994 to 2007. To estimate the fuel consumption in mmBTU, we calculate for fuel $_{i}$ : consumption $\times$ fuel $_{i}$ heat content, for $i=\{$ coal, natural gas, oil $\}$. Coal is the aggregated consumption of bituminous, subbituminous, lignite, waste coal, and synthetic coal. Natural gas is the aggregated consumption of natural gas, other gases, and propane gas. And oil is the aggregated consumption of distillate fuel oil, fuel oil 2, fuel oil 6, petroleum coke, residual fuel oil, kerosene, and jet fuel.

Estimates of fuel prices for coal, natural gas, and oil are based on EIA fuel prices. Due to incomplete or geographically invariant prices, we describe our generation of fuel prices below.

Coal prices are aggregated at the national level (Energy Information Administration, 2011b) for bituminous, sub-bituminous, lignite, anthracite, and total coal prices for each year. To estimate a plant-year specific coal price, for each coal type $\varphi$ (1=bituminous, 2=subbituminous, $3=$ =lignite, $4=$ anthracite) we use the equation:

$$
\frac{\mathrm{q}_{1} \times\left(\mathrm{p}_{1}+\mathrm{c}_{1}\right)+\mathrm{q}_{2} \times\left(\mathrm{p}_{2}+\mathrm{c}_{2}\right)+\mathrm{q}_{3} \times\left(\mathrm{p}_{3}+\mathrm{c}_{3}\right)+\mathrm{q}_{4} \times\left(\mathrm{p}_{4}+\mathrm{c}_{4}\right)}{\mathrm{q}_{1}+\mathrm{q}_{2}+\mathrm{q}_{3}+\mathrm{q}_{4}}
$$

where $\mathrm{q}_{\varphi}$ is the quantity of coal type $\varphi$ used in each state each year, $\mathrm{p}_{\varphi}$ is the national price of coal type $\varphi$, and $c_{\varphi}$ is calculated by the estimates of transportation rates each year

\footnotetext{
${ }^{4}$ Missing plant construction year data and capacity data were occasionally encountered. In these cases data were carried down from previous years.
}

Author's accepted manuscript. Final version published as: Matisoff, D., Noonan, D., \& Cui, J. (2014). Electric utilities, fuel use, and responsiveness to fuel prices. Energy Economics. http://dx.doi.org/10.1016/j.eneco.2014.05.009 
multiplied by the distances from the power plants to the largest source of each type of coal $\varphi$. To calculate the distance from each power plant to the largest mine source of coal, we use McDowell County, West Virginia as the largest source of bituminous coal. Campbell County, Wyoming is the largest producer of sub-bituminous coal. Because the largest source and best grades of lignite occur in the Wilcox Group of strata north of the Colorado River in East and Central Texas, we use Freestone County, which is located in the middle of these strata. And the Continental Strip in Schuylkill County, Pennsylvania produces the largest amount of anthracite coal. Transportation rates data are from the EIA (Energy Information Administration, 2011c) and the distance is calculated using the Stata user generated module geodist (R.Picard, 2010) using the latitudes and longitudes of the counties of plants and coal sources, where county latitudes and longitudes are generated by the Stata module spatdwm (Yu, 2007).

Other prices are simpler to compute. Natural gas prices come from state-year variant natural gas city gate price (Energy Information Administration, 2012). State-level fuel oil price (No.2 distillate end sales price) is only 46 percent complete. We impute missing data using multiple imputation in Amelia II program of R (James Honaker, 2012) using national low sulfur fuel oil prices and incomplete state level No.2 distillate industrial, No.2 diesel end sales, No.2 diesel industrial, and gasoline end sales prices.

To aggregate to the holding company level, plants are summed by the "plant operating holding company” identifier from Ventyx's Velocity Suite, which is derived from FERC form 1. These operating holding companies include large investor owned utilities, such as Xcel, Reliant, Duke, and Southern Company, as well as a variety of municipal electric utilities and rural

\footnotetext{
${ }^{5}$ We use transportation rate of .0209 before year 2002, .0214 for 2002, .0217 for 2003, .0212 for 2004, .0246 for 2005, .0275 for 2006, and .0305 for 2007 (unit: Dollars per Thousand Cubic Feet).
} 
electric co-ops such as Springfield City Water Light and Power, Fayetteville Public Works, or Hoosier Rural Electric co-op, that may own just a few plants. Altogether, there are 214 unique operating holding companies in our dataset. ${ }^{6}$ In addition, to help understand differences between continuous fuel switching and discrete changes in plant operations, we generate subsamples that omit discrete switchers (i.e., observations that had zero use of a fuel in the current or previous year, but not both, and thus where quantifying the percent change in fuel use is problematic). Descriptive statistics (Table 1) demonstrate trends between in price and quantity for fuel use by utilities between 1994 - 2007. On average, coal use increased while oil use decreased. Natural gas use increased, on average, but if discrete changes are excluded, natural gas decreased, at the plant level, suggesting that natural gas plants were built during this time period. Prices of all fuels increased during the time period, though prices of natural gas increased more than prices of coal, and prices of oil increased more than natural gas.

\footnotetext{
${ }^{6}$ We lose a number of observations due to first-differencing and two levels of lags, as well as sporadic missing data. Only those observations that are included in the regressions are displayed in Table 1.
} 
Table 1. Descriptive Statistics of Samples: means (standard deviations)

\begin{tabular}{|l|l|l|l|l|}
\hline Variable & $\begin{array}{l}\text { Plant Level (all } \\
\text { plants) }\end{array}$ & $\begin{array}{l}\text { Plant level } \\
\text { (excluding discrete } \\
\text { switchers) }\end{array}$ & $\begin{array}{l}\text { Holding Company } \\
\text { Level }\end{array}$ & $\begin{array}{l}\text { Holding Company } \\
\text { Level (excluding } \\
\text { discrete switchers) }\end{array}$ \\
\hline$\Delta$ coal use & $.0023(1.4002)$ & $.0128(.2741)$ & $.0240(.4528)$ & $.0235(.3501)$ \\
\hline$\Delta$ natural gas use & $.1058(2.4230)$ & $-.0076(.7007)$ & $.2247(2.3404)$ & $.1230(1.1440)$ \\
\hline$\Delta$ oil use & $-.0938(2.9086)$ & $-.0365(1.0674)$ & $-.0421(2.3909)$ & $.1039(1.3693)$ \\
\hline$\Delta$ coal price & $.0062(.1406)$ & $.0074(.1390)$ & $.0194(.2145)$ & $.0238(.2100)$ \\
\hline$\Delta$ ng price & $.0819(.2225)$ & $.0821(.2203)$ & $.0847(.2303)$ & $.0818(.2315)$ \\
\hline$\Delta$ oil price & $.1013(.2699)$ & $.1002(.2702)$ & $.0989(.2886)$ & $.0975(.2959)$ \\
\hline $\mathrm{N}$ & 6873 & 6101 & 1201 & 991 \\
\hline
\end{tabular}

\section{Methodology and Research Design}

We assume that decision-makers determine fuel use based on previous fuel use and fuel prices. As potential substitutes or complements, we allow the prices of the other two types of fuel to also influence fuel use decisions. Quantities of fuels used by plants (or their holding companies) in any given year are thought to be jointly and simultaneously determined; hence, we put the three relationships into a system of simultaneous equations. Estimating the system of equations using a three-stage least-squares approach allows us to examine the substitution relationships across the three types of fuel. Specifically, we can identify the own-price and crossprice elasticities for each of three different types of fuel.

Of course, there may be other plant- (or holding company-) level unobserved factors that explain fuel use. To account for this possibility and to emphasize the dynamics of the energy markets, we estimate all the models as first-differences. Looking at changes in prices affecting 
changes in quantities in a system that simultaneously estimates the three fuel use equations should mitigate concerns about endogeneity and correlated errors across (fuel) equations. Maintaining the assumption that our unit of observation lacks market power to affect fuel prices (largely linked to global markets) through their quantity choice, the interpretation of exogenous impacts of price changes on quantity adjustments seems all the more plausible.

The basic system of equations begins as:

$$
\begin{aligned}
& \mathrm{y}_{1, \mathrm{t}}=\gamma_{1}+\alpha_{1} \mathrm{t}+\beta_{1} \mathrm{y}_{1, \mathrm{t}-1}+\delta_{1} \mathrm{x}_{\mathrm{t}}+\theta_{1}+\varepsilon_{1, \mathrm{t}} \\
& \mathrm{y}_{2, \mathrm{t}}=\gamma_{2}+\alpha_{2} \mathrm{t}+\beta_{2} \mathrm{y}_{2, \mathrm{t}-1}+\delta_{2} \mathrm{x}_{\mathrm{t}}+\theta_{2}+\varepsilon_{2, \mathrm{t}} \\
& \mathrm{y}_{3, \mathrm{t}}=\gamma_{3}+\alpha_{3} \mathrm{t}+\beta_{3} \mathrm{y}_{3, \mathrm{t}-1}+\delta_{3} \mathrm{x}_{\mathrm{t}}+\theta_{3}+\varepsilon_{3, \mathrm{t}}
\end{aligned}
$$

where $i$ indexes the three fuel types and $t$ indexes time, $\mathrm{y}_{\mathrm{i}, t-1}$ indicates fuel use lagged by one year, $x_{t}$ is a vector of the three fuel prices, $\theta$ is a time-invariant and observation-specific error term, $\varepsilon$ denotes an error term, while $\gamma, \alpha, \beta$, and $\delta$ represent coefficients. This model follows a partial adjustment model, where lagged behavior partly explains current behavior. It also includes a time trend factor $(\alpha)$ in each model. Time-invariant plant-level unobservables, including state PSC actions and policies, are soaked up in $\theta$.

To deal with the potential bias from the unobserved $\theta$, each equation is first-differenced and estimated. The resulting system becomes:

$$
\begin{aligned}
& \Delta \mathrm{y}_{1, \mathrm{t}}=\alpha_{1}+\beta_{1}\left(\Delta \mathrm{y}_{1, \mathrm{t}-1}\right)+\delta_{1}\left(\Delta \mathrm{x}_{\mathrm{t}}\right)+\Delta \varepsilon_{1, \mathrm{t}} \\
& \Delta \mathrm{y}_{2, \mathrm{t}}=\alpha_{2}+\beta_{2}\left(\Delta \mathrm{y}_{2, \mathrm{t}-1}\right)+\delta_{2}\left(\Delta \mathrm{x}_{\mathrm{t}}\right)+\Delta \varepsilon_{2, \mathrm{t}} \\
& \Delta \mathrm{y}_{3, \mathrm{t}}=\alpha_{3}+\beta_{3}\left(\Delta \mathrm{y}_{3, \mathrm{t}-1}\right)+\delta_{3}\left(\Delta \mathrm{x}_{\mathrm{t}}\right)+\Delta \varepsilon_{3, \mathrm{t}}
\end{aligned}
$$

Log terms of all the price and quantity variables are used, which gives the $\beta$ and $\delta$ coefficients the interpretation of supply elasticities. An mmbtu of 0 is replaced by 1 to keep log (mmbtu) 0 instead of missing. This can be particularly important for fuel-switching plants, where $y_{i t}$ or $y_{i t-1}$ are zero, and the notion of a "percent change in quantity” is inevitably problematic. We drop these observations with large swings in fuel use, where $\ln \left(y_{i t}\right)-\ln \left(y_{i t-1}\right)$ involves a 
recode and $|\Delta \ln (y i t)|>1$, from some samples in order to highlight the role of discrete fuelswitching.

The parameters in the first-differenced system of equations are estimated via 3SLS. This allows for (a) correlated errors across equations, and (b) instrumentation for the endogenous lagged fuel use quantities. Similarly to an Arellano-Bond (Arellano and Bond, 1991) estimator, twice-lagged levels of fuel use for each of the three fuel types (i.e., $y_{i, t-2}$ ) serve as instruments in the first-differenced model. These factors should explain variation in the lagged differences in fuels used without belonging in the contemporaneous quantity change equations.

First-stage F statistics included in Tables 2 and 3 show that these twice-lagged levels are good instruments for all three fuels in the holding company model (Table 3) and are good instruments for natural gas and oil in the plant level model. The twice-lagged quantities in the coal equation - perhaps due to the frictions we discuss - may be weak instruments despite being jointly significant in the first-stage coal equation $(\mathrm{F}(3,6866)=14.38)$ in the plant-level model. All equations fail to reject the hypothesis that the exclusion restrictions are invalid, as tested by the Hansen J statistic. While remaining AR2 would be a concern in these Arellano-Bond-style specifications, we do not find evidence of AR2 errors for coal or natural gas. We find some evidence of remaining AR2 error in the oil equation for plant-level data, but not for holding company-level data. We suspect this owes to longer lags in technology-related oil adjustment processes.

Using the plant-level data, we create subsets of the data and apply the same estimation technique to the same basic model. The subsets include the data aggregated up to the holding company level. Because computed coal prices above are plant-specific, coal prices are calculated at the holding company level somewhat differently. To compute coal prices at the holding 
company level, we calculate coal price using $\left(\left(\mathrm{p}_{1}+\mathrm{c}_{1}\right)+\left(\mathrm{p}_{2}+\mathrm{c}_{2}\right)+\left(\mathrm{p}_{3}+\mathrm{c}_{3}\right)+\left(\mathrm{p}_{4}+\mathrm{c}_{4}\right)\right) / 4$. This is similar to before, except $q_{i}$ is omitted, implying an equal weight across all coal sources because many plants use no coal in a given year or only use one type of coal in a given year. In this situation, $\mathrm{C}_{\mathrm{i}}$ is now the transportation rate averaged across all its plants for a given company-year. We aggregate the quantity of fuel used within each holding company-year group as the new dependent variable in the holding company-level data. There are 1,481 such holding-companyyears. We also estimate results based on a subsample of plants that do not have large, discrete switches. (This omits some extremely large values from the data, which might also be influential observations.) 


\section{Results and Discussion}

Table 2. Plant-level fuel use models

\begin{tabular}{|c|c|c|c|c|c|c|}
\hline Sample & \multicolumn{3}{|c|}{ All Plants } & \multicolumn{3}{|c|}{ All Plants Excluding Discrete Switchers } \\
\hline VARIABLES & $\Delta$ coal use & $\begin{array}{l}\Delta \text { natural gas } \\
\text { use }\end{array}$ & $\Delta$ oil use & $\Delta$ coal use & $\begin{array}{l}\Delta \text { natural gas } \\
\text { use }\end{array}$ & $\Delta$ oil use \\
\hline \multirow{2}{*}{$\Delta$ coal price } & 0.007 & 0.299 & $.600 * *$ & $-.079 * *$ & $.336^{* * *}$ & 0.085 \\
\hline & -0.126 & -0.216 & -0.28 & -0.032 & -0.0695 & -0.106 \\
\hline \multirow{2}{*}{$\Delta$ ng price } & $-.250 * * *$ & $-.708 * * *$ & $1.139 * * *$ & $.0938 * * *$ & $-.276 * * *$ & $.354^{* * *}$ \\
\hline & -0.086 & -0.148 & -0.19 & -0.0213 & -0.047 & -0.072 \\
\hline \multirow{2}{*}{$\Delta$ oil price } & -0.059 & 0.0855 & $-.267 *$ & -0.0152 & -0.0161 & $-.146 * * *$ \\
\hline & -0.07 & -0.117 & -0.15 & -0.017 & -0.037 & -0.0565 \\
\hline \multirow{2}{*}{ L. $\Delta$ coal use } & -0.0157 & & & $-.153^{* *}$ & & \\
\hline & -0.155 & & & -0.067 & & \\
\hline \multirow{2}{*}{ L. $\Delta$ ng use } & & -0.0214 & & & $.0805^{* *}$ & \\
\hline & & -0.069 & & & -0.032 & \\
\hline \multirow{2}{*}{ L. $\Delta$ oil use } & & & $.167^{* * *}$ & & & $.063^{* * *}$ \\
\hline & & & -0.035 & & & -0.015 \\
\hline \multirow{2}{*}{ Constant } & 0.029 & $.156^{* * *}$ & $-.155^{* * *}$ & 0.007 & 0.003 & $-.053 * * *$ \\
\hline & -0.019 & -0.033 & -0.041 & -0.005 & -0.011 & -0.015 \\
\hline Observations & \multicolumn{3}{|c|}{6,873} & \multicolumn{3}{|c|}{6,101} \\
\hline $\begin{array}{l}\text { First-Stage F } \\
\text { Statistic }\end{array}$ & 7.831 & 35.56 & 172.1 & 3.112 & 18.92 & 155.7 \\
\hline AR2 & -0.771 & 1.32 & -4.004 & -2.367 & -2.1 & -6.403 \\
\hline Hansen J & \multicolumn{3}{|c|}{0.661} & \multicolumn{3}{|c|}{0.638} \\
\hline
\end{tabular}

Table 2 summarizes the results from the plant level data with two samples. For the first set of models, including all plants during the 1994 - 2007 time period, the time trend (constant) term shows no change of coal use over time, increases of natural gas use, and decreases of oil consumption. The natural gas price is a statistically significant and a strong predictor of fuel use. Increases of natural gas prices are associated with a small negative effect on the quantity of coal consumed, a larger negative effect on the quantity of natural gas consumed, and a large increase of fuel oil consumption. Oil use responds positively to increases in natural gas and coal prices, and decreases in response to increase in oil prices. Coal use is not impacted by changes in coal 
prices. Coal and natural gas consumption are not impacted by past values of consumption, whereas oil use suggests increases in past use lead to increases in current period use. The generally more elastic responses to fuel prices changes for oil use are unsurprising given how power plants' fuel oil use is often seen as more flexible and specialized use unlike the more inelastic, baseload role of coal.

When large, discrete changes are excluded, some changes in fuel use behavior are observed. Time trends no longer exhibit a significant increase of natural gas use. Coal use increases in response to natural gas price increases and decreases in response to increase in coal prices, suggesting a more expected relationship between prices and fuel use behavior. Plants that can more flexibly adjust fuel mix to prices behave rather conventionally (e.g., downward sloping factor demands, coal and gas are substitutes). Decreases of coal use in the past period lead to increases of coal in the current period, suggesting an oscillation response of coal use. In contrast, increases of lagged use for natural gas and oil lead to increases in the current period. 
Table 3. Holding company-level fuel use

\begin{tabular}{|c|c|c|c|c|c|c|}
\hline Sample & \multicolumn{3}{|c|}{ All Plants } & \multicolumn{3}{|c|}{ All Plants Excluding Discrete Switchers } \\
\hline VARIABLES & $\Delta$ coal use & $\begin{array}{l}\Delta \text { natural gas } \\
\text { use }\end{array}$ & $\Delta$ oil use & $\Delta$ coal use & $\begin{array}{l}\Delta \text { natural gas } \\
\text { use }\end{array}$ & $\Delta$ oil use \\
\hline$\Delta$ coal price & $\begin{array}{l}.331 * * * \\
(.061) \\
\end{array}$ & $\begin{array}{l}1.174^{* * *} \\
(.303)\end{array}$ & $\begin{array}{l}.101 \\
(.317) \\
\end{array}$ & $\begin{array}{l}.351 * * * \\
(.052)\end{array}$ & $\begin{array}{l}.504 * * * \\
(.173)\end{array}$ & $\begin{array}{l}-.093 \\
(.204)\end{array}$ \\
\hline$\Delta$ ng price & $\begin{array}{l}.031 \\
(.060) \\
\end{array}$ & $\begin{array}{l}-.452 \\
(.303) \\
\end{array}$ & $\begin{array}{l}.598 * \\
(.316) \\
\end{array}$ & $\begin{array}{l}.020 \\
(.051)\end{array}$ & $\begin{array}{l}-.314^{*} \\
(.168)\end{array}$ & $\begin{array}{l}.286 \\
(.200)\end{array}$ \\
\hline$\Delta$ oil price & $\begin{array}{l}.039 \\
(.048)\end{array}$ & $\begin{array}{l}-.281 \\
(.242)\end{array}$ & $\begin{array}{l}-.078 \\
(.252)\end{array}$ & $\begin{array}{l}.019 \\
(.040)\end{array}$ & $\begin{array}{l}-.147 \\
(.132)\end{array}$ & $\begin{array}{l}-.044 \\
(.156)\end{array}$ \\
\hline L. $\Delta$ coal use & $\begin{array}{l}-.002 \\
(.010) \\
\end{array}$ & & & $\begin{array}{l}-.001 \\
(.009) \\
\end{array}$ & & \\
\hline L. $\Delta$ ng use & & $\begin{array}{l}-.158 * * \\
(.074) \\
\end{array}$ & & & $\begin{array}{l}-.074 * \\
(.043) \\
\end{array}$ & \\
\hline L. $\Delta$ oil use & & & $\begin{array}{l}-.039 \\
(.065) \\
\end{array}$ & & & $\begin{array}{l}-.035 \\
(.048) \\
\end{array}$ \\
\hline Constant & $\begin{array}{l}.012 \\
(.014) \\
\end{array}$ & $\begin{array}{l}.313 * * * \\
(.073) \\
\end{array}$ & $\begin{array}{l}-.085 \\
(.074) \\
\end{array}$ & $\begin{array}{l}.012 \\
(.012) \\
\end{array}$ & $\begin{array}{l}.176^{* * *} \\
(.041) \\
\end{array}$ & $\begin{array}{l}.088^{*} \\
(.046) \\
\end{array}$ \\
\hline Observations & \multicolumn{3}{|c|}{1,201} & \multicolumn{3}{|c|}{991} \\
\hline $\begin{array}{l}\text { First-Stage F } \\
\text { Statistic }\end{array}$ & 125.4 & 27.4 & 44.5 & 92.4 & 28.4 & 33.2 \\
\hline AR2 & -.363 & -1.511 & .749 & .018 & -.985 & -1.079 \\
\hline Hansen J & \multicolumn{3}{|c|}{.086} & \multicolumn{3}{|c|}{.233} \\
\hline
\end{tabular}

Aggregating data to the holding company level (Table 3) shows a different pattern of behavior by decision-makers. Increases in coal prices are associated with increases of both coal use and natural gas use. While increases in natural gas prices are associated with increases of oil use, no other relationships between price and consumption are statistically significant. Time trends demonstrate increasing natural gas use, but are not significant for coal or oil. Decreases in lagged natural gas use are associated with increases in current period natural gas use, suggesting some dynamic adjustments for natural gas. 
Excluding discrete switching plants does not change results substantively. Time trends show a slight increase in oil use and a weaker effect of lagged natural gas use. Increases in natural gas price are associated with slightly less natural gas consumption, but are no longer statistically significantly correlated with oil consumption. Overall, input demand slopes downward only for natural gas, where demand is price inelastic. Coal use actually rises with coal prices across both specifications. ${ }^{7}$

\section{Discussion}

Results do not provide as strong support for fuel substitution as Atkinson and Halvorsen (1976), but show greater responsiveness to fuel prices than Tauchmann (2006). The results also highlight a variety of technological and other market frictions that may impede the implementation of effective energy policy. Below, we relate the findings of our analysis to the hypotheses and discuss these results within the broader body of literature.

Across all models, we find some support for Hypothesis 1 supporting fuel substitution effects across fuels. At the plant level, when all plants are included, natural gas price appears to drive shifts in fuel use - largely shifting between natural gas and fuel oil. When natural gas prices rise, plants appear to shift to fuel oil, and when natural gas prices fall, plants appear to shift away from fuel oil. Strangely, when all plants are included, increases of natural gas prices are associated with decreases of coal use. Correlation between natural gas prices and coal prices $(\mathrm{r}=.29)$ may provide one explanation for this finding. If both natural gas and coal prices are decreasing, then plants may be less likely to respond to decreases of natural gas prices with

\footnotetext{
${ }^{7}$ When two-year lagged differences are added to the model, positive price elasticities for coal become insignificant and negative, suggesting that the coal responsiveness to price is delayed, consistent with our description of the fuel markets.
}

Author's accepted manuscript. Final version published as: Matisoff, D., Noonan, D., \& Cui, J. (2014). Electric utilities, fuel use, and responsiveness to fuel prices. Energy Economics. http://dx.doi.org/10.1016/j.eneco.2014.05.009 
increases of coal use. If natural gas prices are increasing, plants are also unlikely to switch to coal due to technological barriers (a natural gas plant cannot be converted to coal), and environmental regulations that might favor switching towards natural gas but not to coal. If lagged values of changes in energy prices are included in the model, coal and natural gas prices begin to behave more 'normally' in the plant-level data. This suggests that plant investment and fuel decisions are likely impacted by a longer time horizon than the current period. This may be due to the regulatory frictions involved in planning, permitting, gaining approval for, and building a plant.

When excluding “discrete switchers,” those plants that shut down or are newly operating, results appear more consistent with economic theory. Plants respond to increases in coal prices by reducing coal and increasing natural gas use. Plants respond to increases in natural gas prices by increasing coal use and natural gas use. This difference in results suggests that influential discrete switcher observations are responsible for some of the surprising results in the full plantlevel sample. Examining just this subset of discrete switchers (results not shown) suggests that increases in natural gas prices drive reductions of natural gas and coal use, in favor of oil, but that plants may more responsive to past values of fuel prices. While coal appears inelastic in the current period, excluding discrete switchers reveals a negative effect of coal price on coal use. Other specifications show coal demand might be slow to respond to coal price changes. Thus, continuous switchers tend to respond to price signals inelastically (but otherwise as expected) while discrete switchers tend to shut down coal use following coal price hikes, given oscillation in coal prices in these data. This result highlights time lags in responsiveness to prices due to a variety of market, technological, and regulatory frictions that generate a particularly complex 
operating environment for firm and plant managers. Time lags and uncertainties in annual rate cases by PSCs might further distort plant responsiveness.

While natural gas use and oil use suggest a momentum over time - where an increase in past periods predicts an increase in the current period - this relationship for coal use suggests an oscillation of use. This finding may be due to difficulties in coal storage and long-term contracting. Discussions with utility representatives suggested that when natural gas prices drop and utilities shift load to natural gas, coal literally piles up until the piles become so large that the utility will be forced to shift back to coal.

Hypothesis 2 suggests that price elasticities ought to differ for holding companies - either due to the effect of averaging across many plants or the holding company's ability to shift fuels across plants. At the holding company level, coal and natural gas seemed to be highly responsive to coal prices, suggesting a different mechanism than at the plant level. In contrast to the plant level, where natural gas prices appear to be the strongest driver of generation shifts, at the holding company level, coal prices appear to be the largest driver of fuel use. When coal prices rise, firms increase use of natural gas. However, these results show that firms also increase use of coal. This strange finding suggests a variety of barriers that prevent from shifting load away from coal plants. First, as discussed earlier, coal prices and natural gas prices are correlated. If coal prices increase, natural gas prices are also increasing, perhaps generating uncertainties about the projection of future prices of coal and natural gas. Second, when coal prices increase, natural gas use increases substantially - and even more so if discrete switchers are included. This suggests that firms are shifting to natural gas, but this shifting may be limited by existing capacity and the ability to bring new or idled capacity online. The increases in responsiveness when discrete switchers are included suggests that - to some extent - firms do attempt to idle, open, and switch 
plants to take advantage of changing price conditions. Third, during periods of high demand, natural gas pipeline capacity becomes a limiting factor. If pipelines are congested, increases in demand will lead to increases of coal use, in addition to increases of natural gas use.

Interestingly, while at the plant level plants appear responsive to natural gas prices and oil prices, at the firm level they appear much less responsive (though parameter estimates for natural gas consumption are negative and are significant at $\alpha=10$ ). This (lack of) responsiveness suggests that pipeline capacity limitations, contracting, or other frictions inhibit the response of firms to fuel prices. Alternatively, if adjustments occur in smaller capacity plants, the plant level analysis is likely to exaggerate the market's elasticity.

These findings may also be a function of the fuel uses and the patterns of electricity demand. Oil plants tend to fire during peak generation when coal and natural gas plants are already firing at capacity. As a result, while there is some responsiveness to oil prices by oil generation, there is not responsiveness for coal and natural gas consumption to oil prices. Further, the amount of oil generation is so small that oil prices do not register as a driver of any fuel use decisions at the firm level.

We attribute the majority of the disparity with previous literature to modeling and data choices, as well as possible differences in regulatory environments. Atkinson and Halvorsen (1976) discard all observations that do not use substantial amounts of multiple fuels, and focus on specific plants employing a coal-gas, coal-oil, or gas-oil mix. This selection upon the dependent variable limited observations to just a few plants that were likely to engage in fuel substitution. Further, Atkinson and Halvorsen examine just one year of fuel consumption, controlling for plant vintage on the righthand side of the equation. They also derive fuel substitution elasticities from a cross-section of plants, rather than within-plant or within-holding 
company variation. In contrast, Tauchmann (2006) employs a first-differenced model to better control for plant-specific characteristics and technology. We follow this approach.

In complete contrast with Atkinson and Halvorsen, Tauchmann examines discrete shifts in fuel capacity from one type of fuel to another type of fuel, and disregards multifuel boilers in one set of equations, finding little relationship between investment behavior and fuel price ${ }^{8}$. In a second model examining generation and capacity, Tauchmann finds no relationship between fuel prices and either capacity or load factor.

There are several possible explanations for why our results differ from Tauchmann’s. Tauchmann's sample is quite small - examining just 9 holding companies over a long period of time. In contrast, we examine a large number of individual plants and holding companies, and are able to capture much more (plant- and state-specific) variation in fuel price (whereas Tauchmann relies on national average fuel prices). This difference alone is gives us much more statistical power than Tauchmann. In addition, Tauchmann measures load factors and capacities; we are able to capture fuel use more directly and at the plant level, rather than just at the holding company level. Finally, it is possible that the regulatory or market environment in the U.S. has allowed for more fuel substitution than in Germany.

\section{Conclusion}

Using a system of endogenous equations, we find some degree of fuel switching at the plant and holding level in response to changes in price. These results, from data prior to the large boom in natural gas exploration and a decrease in natural gas prices, demonstrate that at the plant level, plants respond to natural gas prices and may substitute natural gas and fuel oil, while at the

\footnotetext{
${ }^{8}$ Tauchmann (2006) finds that oil capacity is discouraged by higher oil prices; for other generation techniques, increases in prices are frequently associated with increased capacity.
} 
holding company level, plants respond to coal prices and substitute natural gas generation and fuel oil for coal generation. This suggests results somewhere between Atkinson and Halvorsen's finding of high responsiveness to fuel prices and Tauchmann's finding of no responsiveness to fuel price changes. These results also highlight a variety of technological, market, and regulatory frictions that temper a plant or utility's responsiveness to fuel prices.

The findings from this study provide multiple directions for future research and exploration. The mechanisms in which state regulations and Public Service Commission decision-making impact fuel choice remain particularly unclear. The role of other market and technological frictions warrants exploration as well. The role that natural gas pipeline capacity, technological lock-in, costs involved with switching fuels, and the role of contracting all likely play a major role in fuel use decisions by electric utilities.

The relative elasticity between coal and natural gas - and the ability of plant and firm managers to respond to price changes in an environment confounded by numerous technological, regulatory, and market frictions - is of concern for energy modelers and those who wish to describe energy investment and consumption decisions as a function of energy prices. This research suggests that level of analysis matters for estimating cross-price elasticities. Further, these results highlight that increases of some fuel prices ought not to be expected to automatically lead to a corresponding adjustment of fuel use and investment.

While results point to some frictions involved with fuel substitution, at least in the short run, it is not entirely clear whether these frictions are driven by decision-makers at the firm or regulatory levels, characteristics of the fuels and contracts, or characteristics of plant technology. Future research - which may take into consideration the recent drop in natural gas prices and investment in natural gas capacity - should seek to test whether market, regulatory 
characteristics, or their interaction has driven fuel use behavior. Together, these results

emphasize that utility behavior is not perfectly responsive to market or regulatory signals, and

that plant and holding company behavior is the result of a complex interaction of technological, regulatory, and market forces.

\section{References}

Arellano M, Bond S. Some Tests of Specification for Panel Data: Monte Carlo Evidence and an Application to Employment Equations. The Review of Economic Studies 1991;58; 277-297.

Atkinson SE, Halvorsen R. Interfuel Substitution in Steam Electric Power Generation. Journal of Political Economy 1976;84; 959-978.

Baron DP, De Bondt RR. Fuel Adjustment Mechanisms and Economic Efficiency. The Journal of Industrial Economics 1979;27; 243-261.

Bopp AE, Costello D. The economics of fuel choice at US electric utilities. Energy Economics 1990;April. Courville L. Regulation and efficiency in the electric utility industry. The Bell Journal of Economics and Management Science 1974; 53-74.

Deng S, Oren S. Electricity derivatives and risk management. Energy 2006;31; 940-953.

Energy Information Administration, 2011a. Annual Energy Outlook 2011. Department of Energy, Washington, D.C.

Energy Information Administration, 2011b. Annual Energy Review, in: 7.9 T (Ed.), Coal Prices, 1949-2010, Washington, D.C.

Energy Information Administration, 2011c. Estimated U.S. Rail Transportation Rates for Coal, State to State, 2001-2008, Washington, D.C.

Energy Information Administration, 2011d. U.S. Energy Related Carbon Dioxide Emissions, 2010, Washington, D.C.

Energy Information Administration, 2012. Natural Gas Citygate Price.

Fabrizio KR. The Effect of Regulatory Uncertainty on Investment: Evidence from Renewable Energy

Generation. Journal of Law, Economics, and Organization 2013;29; 765-798.

Fremeth AR, Holburn GLF. Information Asymmetries and Regulatory Decision Costs: An Analysis of U.S. Electric Utility Rate Changes 1980-2000. Journal of Law, Economics, and Organization 2012;28; 127-162. Galatin M. Economies of Scale and Technological Change in Thermal Power Generation. North-Holland Pub. Co.; 1968.

Graves F, Hanser P, Basheda G, 2006. Electric Utility Automatic Adjustment Clauses: Benefits and Design Considerations. Edison Electric Institute (EEI).

Griffin JM. Inter-fuel substitution possibilities: a translog application to intercountry data. International Economic Review 1977;18; 755-770.

Isaac RM. Fuel Cost Adjustment Mechanisms and the Regulated Utility Facing Uncertain Fuel Prices. The Bell Journal of Economics 1982;13; 158-169.

James Honaker GK, and Matthew Blackwell, 2012. AMELIA II: A Program for Missing Data. Jones CT. A pooled dynamic analysis of interfuel substitution in industrial energy demand by the G-7 countries. Applied Economics 1996;28; 815-821.

Joskow PL. California's electricity crisis. Oxford Review of Economic Policy 2001;17; 365-388.

Joskow PL, Mishkin FS. Electric Utility Fuel Choice Behavior in the United States. International Economic Review 1977;18; 719-736.

Author's accepted manuscript. Final version published as: Matisoff, D., Noonan, D., \& Cui, J. (2014). Electric utilities, fuel use, and responsiveness to fuel prices. Energy Economics. http://dx.doi.org/10.1016/j.eneco.2014.05.009 
Kaserman DL, Tepel RC. The Impact of the Automatic Adjustment Clause on Fuel Purchase and Utilization Practices in the U. S. Electric Utility Industry. Southern Economic Journal 1982;48; 687-700. Mansur ET, Mendelsohn R, Morrison W. Climate change adaptation: A study of fuel choice and consumption in the US energy sector. Journal of Environmental Economics and Management 2008;55; 175-193.

Matisoff DC. The Adoption of State Climate Change Policies and Renewable Portfolio Standards: Regional Diffusion or Internal Determinants? Review of Policy Research 2008;25.

Michaels RJ. Fuel cost adjustments: An idea whose time has gone. Electricity Journal;(United States) $1994 ; 7$.

Morgan RE. Time to face FACs: How fuel clauses undermine energy efficiency. The Electricity Journal 1993;6; 34-41.

Mountain D. Imported electricity: A substitute for inputs used by the regional electricity industry. Journal of Regional Science 1982;22; 83-96.

Petrash JM. Long-Term Natural Gas Contracts: Dead, Dying, or Merely Resting. Energy LJ 2006;27; 545. Pindyck RS. Interfuel substitution and the industrial demand for energy: an international comparison. The Review of Economics and Statistics 1979;56; 169-177.

Seifi A, McDonald JF. Fuel Choice in New Fossil Fuel Electric Power Plants. Resources and Energy 1986;8; 21-35.

SNL Energy, 2014. Regional Power Markets Summary.

Söderholm P. Fuel flexibility in the West European power sector. Resources Policy 2000;26; 157-170.

Tauchmann H. Firing the furnace? An econometric analysis of utilities fuel choice. Energy Policy 2006;34; 3898-3909.

Uri N. Regional interfuel substitution by electric utilities in the United States. Journal of Regional Science $1977 ; 17 ; 217-226$.

Author's accepted manuscript. Final version published as: Matisoff, D., Noonan, D., \& Cui, J. (2014). Electric utilities, fuel use, and responsiveness to fuel prices. Energy Economics. http://dx.doi.org/10.1016/j.eneco.2014.05.009 